\title{
PENGARUH POINT OF PURCHASE (POP) TERHADAP KEPUTUSAN PEMBELIAN PRODUK PAKAIAN DI PT. MATAHARI DEPARTMENT STORE KOTA BENGKULU 1); Sukardi Putra'); Furqonti Ranidiah ${ }^{3)}$; Ade Tiara Yulinda \\ 1) Department of Management, Faculty of Economic and Business, Universitas Muhammadiyah Bengkulu \\ 2) Department of Accountancy, Faculty of Economic and Business, Universitas Muhammadiyah Bengkulu \\ ${ }^{3)}$ Department of Management, Faculty of Economic and Business, Universitas Muhammadiyah Bengkulu
}

Email: ${ }^{1)}$ ardisix@gmail.com; ${ }^{2)}$ furqonti.ranidiah@gmail.com ${ }^{3)}$ ade91tiarayulinda@gmail.com

\section{How to Cite :}

Putra, S. (2020). Pengaruh point of purchase (pop) terhadap keputusan pembelian produk pakaian di pt. Matahari department store kota bengkulu. EKOMBIS REVIEW: Jurnal IImiah Ekonomi Dan Bisnis, 8(2). DOI: https://doi.org/10.37676/ekombis.v8i2

\section{ARTICLE HISTORY}

Received [28 06 2020]

Revised [15 07 2020]

Accepted [28 07 2020]

\section{KEYWORDS}

Point of Purchase

(POP), Purchasing Decisions

This is an open access article under the $C C-B Y-S A$ license

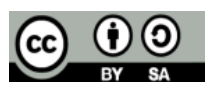

\section{ABSTRAK}

Tujuan penelitian untuk mengetahui pengaruh In Store Media , Signane dan Display terhadap keputusan pemebelian produk pakaian di PT. Matahari Department Store. Metode Penelitian ini menggunakan penelitian kuantitatif,populasi dalam penelitian ini adalah seluruh konsumen PT. Matahari Department Store Kota Bengkulu yang berjumlah 120 orang. Teknik Pengumpulan Data menggunakan observasi , kuesioner. Teknik analisis yang digunakan yaitu Uji Regresi Linear Berganda. Hasil Penelitian menunjukan In Store Media berpengaruh terhadap Keputusan Pembelian pada Produk Pakaian di PT. Matahari Department Store Kota Bengkulu, hal ini dibuktikan dengan hasil uji $t$ menunjukan nilai $t_{\text {hit }}>t_{\alpha / 2}(8.193$ $>1.9840$ ) dan ( $\operatorname{sig} \alpha=0,000<0,050)$. Signane berpengaruh signifikan terhadap Keputusan Pembelian pada Produk Pakaian di PT. Matahari Department Store Kota Bengkulu, hal ini dibuktikan dengan hasil uji t menunjukan nilai $\mathrm{t}_{\text {hit }}>\mathrm{t}_{\alpha / 2}(2.689>1.9840)$ dan $(\mathrm{sig}$ $\alpha=0,043<0,050$ ). Display berpengaruh signifikan terhadap Keputusan Pembelian pada Produk Pakaian di PT. Matahari Department Store Kota Bengkulu, hal ini dibuktikan dengan hasil uji $\mathrm{t}$ menunjukan nilai $\mathrm{t}_{\text {hit }}>\mathrm{t}_{\alpha / 2}(2.480>1.9840)$ dan $(\operatorname{sig} \alpha=0,034$ $<0,050)$. Koefisien determinasi $\mathrm{R}^{2}=0,646$ nilai mempunyai makna bahwa In Store Media $\left(\mathrm{X}_{1}\right)$, Signane $\left(\mathrm{X}_{2}\right)$, dan Display $\left(\mathrm{X}_{3}\right)$ memberikan kontribusi yang signifikan pengaruh sebesar 0, 646 atau 64,6\% terhadap Keputusan Pembelian (Y) pada Produk Pakaian di PT.

192 I Sukardi Putra; Furqonti Ranidiah; Ade Tiara Yulinda; Pengaruh Point Of Purchase (Pop)... 


\begin{abstract}
The objective of this research was to determine the effect of Purchase Point (POP) toward The Purchasing Decision on Clothing Products at PT. Matahari Department Store Bengkulu City. The research method of this study was quantitative research method. The population of this study were all of consumers of PT. Matahari Department Store Bengkulu City. It was 120 people. The data collection techniques of this study used observation and questionnaire. The analysis technique of this study used the Multiple Linear Regression Test. The results of this study show that there is effect Purchase Point (POP) toward The Purchasing Decision on Clothing Products at PT. Matahari Department Store Bengkulu City. It was proved by the result of the test that the value of $t_{-}$hit $>t_{-}(\alpha / 2) \quad(8.193>1.9840)$ and (sig $\alpha=$ $0.000<0.050$ ). In other word that it has significant influence on Purchasing Decisions on Clothing Products at PT. Matahari Department Store Bengkulu City, this is evidenced by the results of the $t$ test showing the value of $t_{-}$hit $>t_{-}(\alpha / 2)$ $(2.689>1.9840)$ and (sig $\alpha=0, .043<0.050)$. Display significantly influence the Purchasing Decision on Clothing Products at PT. Matahari Department Store Bengkulu City. This is evidenced by the results of the test showing the value of $t_{-}$hit $>t_{-}(\alpha / 2)(2.480>1.9840)$ and $(\operatorname{sig} \alpha=0.034<0.050)$. The coefficient of determination $R^{\wedge} 2=0.646$ values. It has the meaning that In Store Media $\left(X_{-} 1\right)$, Signane $(X 2)$, and Display (X3) contribute significantly to the influence of 0.646 or $64.6 \%$ of the Purchasing Decision (Y) on Clothing Products at PT. Matahari Department Store Bengkulu City..
\end{abstract}

\title{
PENDAHULUAN
}

Di era globalisasi, dalam menjalankan bisnis perusahaan menghadapi persaingan bisnis yang semakin ketat. perusahaan harus dapat memilih dan melaksanakan strategi yang tepat. Persaingan bisnis dalam era globalisasi menuntut perusahaan untuk mampu bertindak cepat dan tepat dalam menghadapi persaingan di lingkungan bisnis yang dinamis.Sudah menjadi tujuan perusahaan untuk tanggap dalam memenangkan persaingan dan memperkuat daya saing agar dapat menghasilkan kinerja dan keuntungan yang tinggi.Untuk memenangkan persaingan, maka perusahaan harus dapat mempengaruhi calon pembeli untuk kemudian membeli produk atau jasanya, sehingga diharapkan keuntungan perusahaan dapat meningkat dan persaingan bisnis dapat dimenangkan.Oleh karena itu, setiap perusahaan dituntut untuk memiliki strategi dalam memenangkan persaingan bisnis.

Dalam persaingan yang tajam seperti ini, keberhasilan perusahaan banyak ditentukan oleh ketepatan perusahaan dalam memanfaatkan peluang dan mengidentifikasi kegiatan-kegiatan individu dalam usahanya mendapatkan dan menggunakan barang ataupun jasa yang termasuk didalamnya proses keputusan konsumen. Banyak perusahaan yang berusaha memenangkan persaingan dengan cara memanfaatkan peluang bisnis yang ada dan berusaha menerapkan point of purchase yang tepat dalam rangka menguasai pasar. 
Point of purchase (POP) merupakan bahan atau material yang digunakan untuk menarik perhatian pembeli terhadap merek, menginformasikan manfaat utama merek, atau menampilkan informasi harga.Salah satu tujuan perusahaan adalah untuk mempertahankan eksistensi kinerjanya untuk mencapai suatu tingkat pertumbuhan tertentu. Perusahaan tersebut akan berusaha menguasai pangsa pasar dengan berbagai Point of purchase dan juga pelayanannya dengan tujuan akhir mendapatkan laba maksimal dengan tingkat efisiensi kinerja secara optimal (Semenik et al, 2012: 622)

Banyak faktor yang mempengaruhi perilaku konsumen dalam keputusan pembelian barang atau jasa. Mempelajari dan menganalisa perilaku konsumen dalam keputusan pembelian barang atau jasa adalah hal yang penting, sebab dengan pengetahuan dasar yang baik mengenai perilaku konsumen akan dapat memberikan masukan yang berarti, salah satu yang mempengaruhi perilaku konsumen dalam keputusan pembelian adalah perencanaan point of purchase.

Perusahaan harus mampu mengenali secara dini apa yang menjadi kebutuhan dan harapan konsumen saat ini maupun masa yang akan datang. Disinilah dibutuhkan seorang manajer pemasaran yang mempunyai pengetahuan seksama tentang perilaku konsumen agar dapat memberikan definisi pasar yang baik untuk mengikuti perubahan yang terus-menerus ini, serta untuk merancang point of purchase (pop) yang tepat, adapun pengukuran dari point of purchase (POP) meliputi; in store media, signane dan Display.

In Store Media merupakan perangkat point of purchase (POP) yang paling baru.Di mana perangkat atau variabel point of purchase (POP) tersebut yang memanfaatkan video atau radio di dalam toko.Salah satu komponen utama yang digunakan dalam in store media ini adalah musik yang memainkan peran penting dalam pembuatan keputusan pembelian konsumen.Oleh karena itu, musik memiliki peranan penting dalam mempengaruhi konsumen melakukan pembelian. Indikator dari In Store Media meliputi: musik, jingle, musik latar, nada-nada popular dan arasemen klasik (Terence A. Shimpm: 2003).

Signage merupakan perangkat point of purchase (POP) yang berupa tanda-tanda tentang suatu produk yang berada di dalam toko seperti informasi harga, keunggulan suatu produk tertentu dan lain-lain. Dengan informasi tersebut, konsumen akan lebih mudah mendapat informasi dan mencocokkan dengan barang yang dibutuhkan. Signage terdiri dari beberapa jenis, yaitu poster yang merupakan gambar-gambar untuk menarik perhatian konsumen di dalam toko dan menunjang penataan barang lebih memikat. Label harga, adalah informasi tentang harga suatu produk, yang membuat konsumen dapat mempertimbangkan dengan mudah untuk membeli. Indikator dari Signage terdiri dari: poster, label harga, papan promosi dan papan petunjuk letak produk (Terence A. Shimpm, 2003).

Display adalah usaha yang dilakukan untuk menata barang yang mengarahkan pembeli agar tertarik untuk melihat dan membeli. Display merupakan pemajangan atau tata letak barang dagangan untuk menarik minat beli konsumen agar terciptanya pembelian. Tujuan dari Display yaitu Menarik perhatian pembeli dilakukan dengan cara menggunakan warna-warna, lampu lampu dan sebagainya dan Menimbulkan keinginan memiliki barang-barang yang dipamerkan di toko tersebut, setelah masuk ke toko, kemudian melakukan pembelian. Indikator dari Display terdiri dari: Window Display, Interior Display dan Eksterior Display (Terence A. Shimpm, 2003).

PT. Matahari Department Store adalah bisnis komersial yaitu kegiatan usaha yang menjual barang dan jasa kepada konsumennya untuk kegunaan pribadi dan keluarga.PT. Matahari Department Store adalah salah satu perusahaan terkemuka di Indonesia yang menyediakan perlengkapan pakaian, aksesoris, produk-produk kecantikan dan rumah tangga dengan harga terjangkau.PT. Matahari Department Store bermitra dengan pemasok - pemasok

194 | Sukardi Putra; Furqonti Ranidiah; Ade Tiara Yulinda; Pengaruh Point Of Purchase (Pop)... 
terpercaya di Indonesia dan luar negeri untuk menyediakan kombinasi barang-barang berkualitas tinggi yang dapat diterima olehsemua konsumen.

Berdasarkan observasi pada PT. Matahari Department Store, PT. Matahari Department Storesudah menunjukan adanya point of purchase (POP) sebagai media promosi akan tetapi peneliti menemukan permasalahan pada In Store Media yang menggunakan video atau radio di dalam toko. Aransemen PT. Matahari Department Store yang digunakan belum maksimal menyalurkan pesan-pesan penjualan. Berdasarkan observasi, pesan penjualan yang diperdengarkan di PT. Matahari Department Store durasinya terlalu cepat dan hanya diperdengarkan pada jam-jam tertentu sedangkan musik-musik atau instrumen lainnya lebih lama durasinya.

Pada point Signage PT. Matahari Department Store hanya memberikan informasi harga atau diskon namun tidak menampilkan secara rinci mengenai produk yang dijual misalnya material, size dan keunggulan produk yang dijual. Sedangkan pada aspek Display berdasarkan observasi, PT. Matahari Department Store belum menata barang yang mengarahkan pembeli agar tertarik untuk melihat dan membeli. Misalnya pada barang yang didiskon tidak dilengkapi dengan warna-warna yang menarik perhatian pengunjung, lampu lampu dan sebagainya dan agar menimbulkan keinginan konsumen memiliki barang-barang yang dipamerkan. Permasalahan lain pada aspek display yaitu penggunaan window display. Window Display adalah pemajangan barang dagangan di etalase atau jendela kegiatan usaha.Window displayPT. Matahari Department Store hanya memperlihatkan barang dagangan yang ditawarkan saja, tanpa dapat disentuh oleh konsumen, hal ini mengakibatkan konsumen justru enggan melakukan pembelian terhadap produk yang dipajang di window display. Jika dibandingkan penggunaan window display pada PT. Matahari Department Store dengan departemen store lain misalnya Bucheri, yang menggunakan window display. Di Bucheri konsumen diberi akses untuk melihat langsung bahkan mencoba barang yang dipajang di window display sedangkan di PT. Matahari Department Store, konsumen hanya diperbolehkan melihat saja, tanpa menyentuh barang yang dipajang.Berdasarkan latar belakang ini di atas, peneliti tertarik untuk meneliti Untuk mengetahui pengaruh point of purchase (POP) terhadap keputusan Pembelian produk pakaian di PT. Matahari Department Store Kota Bengkulu.

\section{LANDASAN TEORI}

\section{Pengertian Keputusan Pembelian Konsumen}

Pengambilan keputusan dapat diartikan sebagai suatu proses penilaian dan pemilihan dari berbagai alternatif sesuai dengan kepentingan-kepentingan tertentu dengan menetapkan suatu pilihan yang dianggap paling menguntungkan. Kalau ada dua atau lebih pilihan alternatif dan dari dua pilihan tersebut konsumen harus memilih salah satu dari dua atau lebih alternatif yang ada, maka pemilihan salah satu dari alternatif yang ada tersebut tidak lain adalah proses pengambilan keputusan.

Menurut Boyd Walker (2007) pengambilan Keputusan Pembelian konsumen merupakan sebuah pendekatan penyelesaian masalah pada kegiatan manusia membeli suatu produk guna memenuhi keinginan dan kebutuhannya.Menurut Kotler (2009), indikator- indikator dalam keputusan pembelian adalah:

1. Kemantapan pada sebuah produk, merupakan keputusan yang dilakukan konsumen, setelah mempertimbangkan berbagai informasi yang mendukung pengambilan keputusan.

2. Kebiasaan dalam membeli produk, merupakan pengalaman orang terdekat (orang tua, saudara) dalam menggunakan suatu produk.

3. Memberikan rekomendasi kepada orang lain, merupakan penyampaian informasi yang positif kepada orang lain, agar tertarik untuk melakukan pembelian. 
4. Melakukanpembelian ulang,merupakan pembelian yang berkesinambungan, setelah konsumen merasakan kenyamanan atas produk atau jasa yang diterima.

\section{Point Pembelian (Point Of Purchase)}

Semenik et al (2012:622) mendefinisikan Point Of Purchase (POP) sebagai bahan atau material yang digunakan untuk menarik perhatian pembeli terhadap merek, menginformasikan manfaat utama merek, atau menampilkan informasi harga. POP juga menampilkan penawaran harga atau promosi penjualan konsumen lainnya.

Nyken Widyastuti dan Retno Tanding Suryandari (2004) dalam jurnal pengaruh point of purchase dalam perilaku pembelian konsumen menyederhanakan perangkat POP menjadi tiga, yaitu : In Store Media, Signage dan Display.

\section{$\underline{\text { In Store Media }}$}

Menurut Goni (1991) in store media merupakan perangkat POP Advertising terbaru yang mempunyaitujuanyangsama denganduaperangkatdasar POP Advertising lainnya.In Store Media menyajikanmusikpada beberapabagiantokogunamembangunsuasanayang nyaman yang mengiringikonsumendalamberbelanjadengan menggunakanaudiodanvideo.Agar dapatmencapaitujuan tersebut, disesuaikan dengan selerasebagian besarkonsumen yang berbelanjapadasaatitu.

Terence A. Shimp (2003:487) menyatakan bahwa musik, jingle, musik latar, nada-nada popular, dan arasemen klasik digunakan untuk menarik perhatian, menyalurkan pesan- pesan penjualan, menentukan emosional untuk iklan dan mempengaruhi suasana hati para pendengar. Sedangkan Ujang Sumarwan (2011:377) menyatakan bahwa musik merupakan bagian dari tata suara yang akan menimbulkan suasana yang menyenangkan bagi konsumen, sehingga mereka bisa lebih lama berbelanja dan membeli barang. Dengan demikian, musik memiliki pengaruh terhadap keputusan konsumen dalam melakukan pembelian. Adapun Indikator In Store Media menurutTerence A. Shimp (2003:487) meliputi :

1. Musik digunakan untuk menarik perhatian, menyalurkan pesan-pesan penjualan, menentukan emosional untuk iklan dan mempengaruhi suasana hati para pendengar.

2. Jingle digunakan untuk menarik perhatian, menyalurkan pesan-pesan penjualan, menentukan emosional untuk iklan dan mempengaruhi suasana hati para pendengar.

3. Musik latar digunakan untuk menarik perhatian, menyalurkan pesan-pesan penjualan, menentukan emosional untuk iklan dan mempengaruhi suasana hati para pendengar.

4. Nada-nada popular digunakan untuk menarik perhatian, menyalurkan pesan- pesan penjualan, menentukan emosional untuk iklan dan mempengaruhi suasana hati para pendengar.

5. Aransemen klasik digunakan untuk menarik perhatian, menyalurkan pesan- pesan penjualan, menentukan emosional untuk iklan dan mempengaruhi suasana hati para pendengar.

\section{Signane}

Kata Signage berasal dari kata sign. Sign sebagai kata benda memiliki arti yang cukup luas karena memiliki arti yang berbeda-beda tergantung pada ruang lingkupnya. Beberapa arti sign antara lain, (Rini Suryantini, 2001):

1. Sebuah tampilan publik atau sebuah pesan

2. Sebuah persepsi yang mengindikasikan sesuatu sebagai petunjuk yang terlihat bahwa sesuatu telah terjadi

3. Tingkah laku atau gerakan sebagai bahasa isyarat

196 | Sukardi Putra; Furqonti Ranidiah; Ade Tiara Yulinda; Pengaruh Point Of Purchase (Pop)... 
Menurut Lawrence K Frank (2011), arti Signage adalah pesan atau informasi yang muncul secara berturut-turut atau teratur dalam hubungannya dengan tanda- tanda yang penting dan menimbulkan respon manusia.Adapun Indikator Signage menurutTerence A. Shimp (2003:487) meliputi :

1. Poster

Poster yang merupakan gambar-gambar untuk menarik perhatian konsumen di dalam toko dan menunjang penataan barang lebih memikat.

2. Label harga

Label harga, adalah informasi tentang harga suatu produk, yang membuatkonsumen dapat mempertimbangkan dengan mudah untuk membeli.

3. Papan promosi

Papan promosi, digunakan untuk mengumumkan sesuatu. Biasanyadiletakkan di depan toko.

4. Papan petunjuk letak produk

Papan petunjuk letak produk, digunakan untuk memudahkan konsumen dalam mendapatkan produk yang diinginkan.Selain itu, papan petunjuk juga digunakan sebagai salah satu bentuk komunikasi yaitu promosional sign, locational sign, dan institutional sign.

\section{Display}

Sopiah dan Syihabudhin (2008) menyatakan bahwa Display adalah usaha yang dilakukan untuk menata barang yang mengarahkan pembeli agar tertarik untuk melihat dan membeli. Display merupakan pemajangan atau tata letak barang dagangan untuk menarik minat beli konsumen agar terciptanya pembelian.

Bob Faster (2008) menyatakan bahwa Display adalah keinginan membeli sesuatu, yang tidak didorong oleh seseorang tapi didorong oleh daya tarik, ataupun oleh penglihatan, ataupun oleh perasaan lainnya. Dengan demikian hanya dengan melihat barang dagangan disertai dengan penataan barang yang bagus maka konsumen akan tertarik serta memudahkan konsumen dalam memilih barang yang diinginkan. Adapun Indikator DisplaymenurutTerence A. Shimp (2003:487) meliputi:

1. Window Display

Window Display yang merupakan pemajangan barang dagangan di etalase atau jendela kegiatan usaha.Tujuan window Display adalah untuk menarik minat konsumen sekaligus menjaga keamanan barang dagangan.Window Display hanya memperlihatkan barang dagangan yang ditawarkan saja, tanpa dapat disentuh oleh konsumen, sehingga pengamanan menjadi lebih mudah. Bila konsumen ingin mengetahui lebih lanjut, maka ia dipersilahkan untuk lebih masuk dan memperjelas pengamatannya. Window Display juga merupakan Display yang sering digunakan di pasar swalayan berupa penataan suatu produk dalam rak khusus di area tertentu dalam toko, terpisah dari produk lain.

2. Interior Display

Interior Display yang merupakan pemajangan barang dagangan di dalam toko.Interior Display banyak dipergunakan untuk barang-barang yang sudah dikenal luas oleh masyarakat.

3. Eksterior Display

Eksterior Display yang merupakan pemajangan barang dagangan di tempat tertentu di luar kegiatan usaha yang biasa digunakan. Pemajangan sistem ini banyak digunakan untuk promosi barang, pengenalan produk baru, penjualan istimewa seperti cuci gudang, discount dan sejenisnya.

\section{Pengaruh In Store Media terhadap Keputusan Pembelian Konsumen}

In Store Media merupakan perangkat perangkat atau variabel point of purchase (POP) yang memanfaatkan video atau radio di dalam toko. Salah satu komponen utama yang 
digunakan dalam in store media ini adalah musik yang memainkan peran penting dalam pembuatan keputusan pembelian konsumen.

Musik merupakan salah satu indikator in store media, musik memiliki peranan penting dalam mempengaruhi konsumen melakukan pembelian. Terence A. Shimp (2003) menyatakan bahwa musik, jingle, musik latar, nada-nada popular, dan arasemen klasik digunakan untuk menarik perhatian, menyalurkan pesanpesan penjualan, menentukan emosional untuk iklan dan mempengaruhi suasana hati para pendengar sehingga suasana hati konsumen yang mendengar merasa nyaman untuk melakukan pemilihan terhadap barang atau jasa sehingga mempengaruhi keputusan konsumen melakukan pembelian.

\section{Pengaruh Signane terhadap Keputusan Pembelian Konsumen}

Hasil penelitian Novrianto dkk (2016) mengemukakan perilaku konsumen tertarik dengan promosi. Signage sebagai media promosi yang mudah terlihat, memberikan dampak signifikan terhadap keputusan pembelian tidak terencana. Atribut-atribut yang diuji dalam dimensi Signage adalah poster yang terpasang, desain poster, label harga yang terlihat jelas dan gampang dilihat, papan promosi, dan papan petunjuk yang menarik. Penelitian Pamungkas (2013) signage mempunyai pengaruh yang positif terhadap variabel keputusan pembelian konsumen. Hasil penelitian ini mengemukakan setiap peningkatan satu unit variabel signage dengan asumsi variabel bebas lain konstan akan menyebabkan kenaikan keputusan pembelian konsumendan ada disetiap sudut tempat berdampak positif terhadap keputus

\section{Pengaruh Display terhadap Keputusan Pembelian Konsumen}

Display adalah usaha yang dilakukan untuk menata barang yang mengarahkan pembeli agar tertarik untuk melihat dan membeli. Display merupakan pemajangan atau tata letak barang dagangan untuk menarik minat beli konsumen agar terciptanya pembelianan pembelian.

Kasali (1992) mengemukakan display digunakan untuk mendukung penjualan perusahaan. Ketika berada di dalam sebuah toko, sering kali kita pada akhirnya membeli barang yang sebenarnya tidak menjadi barang utama yang ingin kita beli. Bisa jadi karena barang tersebut sedang didiskon, atau kita tergiur oleh promosi dan fitur-fitur yang disajikan melalui banyak tulisan yang ada di dalam toko. Ketika kita melakukan pembelian tersebut, secara tidak langsung kita telah terpengaruh oleh display yang ada di dalam toko itu.

\section{Metode Analisis}

\section{METODE PENELITIAN}

Metode yang digunakan adalah Analisis deskriptif kualitatif digunakan untuk menggambarkan fenomena-fenomena yang terjadi dilapangan berdasarkan variavel-variabel penelitian pengamatan dan persepsi responden terhadap variabel yang digunakan penelitian ini. Metode rata-rata (mean) digunakan rumus (cooper dan Emory, 2006).

$$
\begin{aligned}
& R x y= \\
& \text { Dimana: } \\
& \text { F = Frekuensi jawaban responden } \\
& \mathrm{X}=\text { Skor jawaban responden } \\
& \mathrm{N}=\text { Jumlah Sampel }
\end{aligned}
$$

Selanjutnya dihitung juga skala interval jawaban responden yang bertujuan untuk memudahkan interprestasi hasil dengan rumus (Cooper dan Emory, 2006).

Skala interval $=$

198 | Sukardi Putra; Furqonti Ranidiah; Ade Tiara Yulinda; Pengaruh Point Of Purchase (Pop)... 
Dimana :

$\mathrm{U}=$ Skala jawaban tertinggi

$\mathrm{L}=$ Skor jawaban terendah

$\mathrm{K}=$ Jumlah kelas interval

Dari rumus di atas, maka skala interval yang digunakan dalam penelitian ini adalah :

Dik :

Skor jawaban tertinggi $\quad(\mathrm{U})=5$

Skor jawaban terendah $\quad(\mathrm{L})=1$

Jumlah kelas interval $\quad(\mathrm{K})=5$

Skala interval $=\quad=\quad=0.80$

Jadi jarak (skala) setiap kelas interval sebesar 0,80, dari skala interval tersebut, selanjutnya diinterprestasikan ke dalam rata-rata jawaban responden dengan kriteria:

Tabel 1. Kriteria Penilaian Tanggapan Responden

\begin{tabular}{|l|l|}
\hline Interval Penliaian & Kategori Penilaian \\
\hline $4,20-5,00$ & Sangat setuju \\
\hline $3,40-4,19$ & Setuju \\
\hline $2,60-3,39$ & Netral \\
\hline $1,80-2,59$ & Tidak setuju \\
\hline $1,00-1,79$ & Sangat tidak setuju \\
\hline
\end{tabular}

Sumber : Sugiyono, (2010:91)

\section{HASIL DAN PEMBAHASAN}

\section{Pembahasan}

\section{Analisis Regresi Linear Berganda}

Analisis regresi linear berganda yang akan dibahas dalam penelitian ini sehingga penulis bisa menggambarkan mengenai tanggapan responden (In Store Media, Signane dan Display) terhadap Keputusan PembelianPada Produk Pakaian di PT. Matahari Department Store Kota Bengkulu. Berdasarkan estemasi regresi linier berganda dengan menggunakan program SPSS Versi 24, 0 For Windows, maka diperoleh tabel dibawah ini :

Tabel 2. Hasil Analisis Regresi Linear Berganda

\begin{tabular}{|c|c|c|c|c|c|}
\hline \multicolumn{6}{|c|}{ Coefficients $^{\mathrm{a}}$} \\
\hline \multirow[b]{2}{*}{ Model } & \multicolumn{2}{|c|}{$\begin{array}{l}\text { Unstandardized } \\
\text { Coefficients }\end{array}$} & \multirow{2}{*}{$\begin{array}{c}\begin{array}{c}\text { Standardize } \\
\text { d Coefficients }\end{array} \\
\text { Beta }\end{array}$} & \multirow[b]{2}{*}{$\mathbf{T}$} & \multirow[b]{2}{*}{ Sig. } \\
\hline & B & $\begin{array}{l}\text { Std. } \\
\text { Error }\end{array}$ & & & \\
\hline (Constant) & 3.885 & .886 & & 4.386 & .000 \\
\hline In Store Media & .649 & .079 & .799 & 8.193 & .000 \\
\hline Signane & .229 & .085 & .209 & 2.689 & .008 \\
\hline Display & .235 & .095 & .210 & 2.480 & .015 \\
\hline
\end{tabular}

a. Dependent Variable: Keputusan Pembeliann

Sumber: Output SPSS 24, 0

Dari perhitungan hasil diatas didapatkan persamaan regresinya adalah sebagai berikut :

$\mathrm{Y}=3.885+0.649(\quad)+0.229\left(\mathrm{X}_{2}\right)+0.235\left(\mathrm{X}_{3}\right)$ 
Berdasarkan persamaan regresi diatas, maka dapat dijelaskan sebagai berikut :

1. Nilai Konstanta 3.885 mempunyai arti bahwa apabila variabel In Store Media ( ), Signane $\left(\mathrm{X}_{2}\right)$ dan Display $\left(\mathrm{X}_{3}\right)$ terhadap Keputusan Pembelian(Y) sama dengan nol, maka variabel Keputusan Pembeliannakan tetap yaitu 3.885 apabila variabel In Store Media ( ）, Signane $\left(\mathrm{X}_{2}\right)$ dan Display $\left(\mathrm{X}_{3}\right)$ terhadap Keputusan Pembeliann(Y) sama dengan nol.

2. Koefisien Regresi , sebesar 0.649 mempunyai makna jika nilai variabel In Store Media ( ) naik satu satuan maka nilai Keputusan Pembelian(Y) akan naik sebesar 0.649.

3. Koefisien Regresi , sebesar 0.229 mempunyai makna jika nilai variabel Signane ( ) naik satu satuan maka nilai Keputusan Pembelian(Y) akan naik sebesar 0.229 dengan asumsi variabel Signane( ) dianggap tetap.

4. Koefisien Regresi , sebesar 0.235 mempunyai makna jika nilai variabel Display ( ) naik satu satuan maka nilai Keputusan Pembeliann(Y) akan naik sebesar 0.235 dengan asumsi variabel Display $\left(\mathrm{X}_{3}\right)$ dianggap tetap.

\section{Pengujian Hipotesis Dengan Uji t}

Untuk menguji pengaruh variabel bebas secara parsial terhadap variabel terikat digunakan uji t sebagai berikut :

Tabel 3. Hasil Pengujian Hipotesis dengan Uji t

\begin{tabular}{|c|c|c|c|c|c|c|}
\hline \multicolumn{7}{|c|}{ Coefficients $^{\mathrm{a}}$} \\
\hline & \multirow[b]{2}{*}{ Model } & \multicolumn{2}{|c|}{$\begin{array}{l}\text { Unstandardized } \\
\text { Coefficients }\end{array}$} & \multirow{2}{*}{$\begin{array}{c}\begin{array}{c}\text { Standardiz } \\
\text { ed Coefficients }\end{array} \\
\text { Beta }\end{array}$} & \multirow[b]{2}{*}{$\mathrm{T}$} & \multirow[b]{2}{*}{ Sig. } \\
\hline & & $\mathrm{B}$ & Std. Error & & & \\
\hline \multirow{4}{*}{ I } & (Constant) & 3.885 & .886 & & 4.386 & .000 \\
\hline & In Store Media & .649 & .079 & .799 & 8.193 & .000 \\
\hline & Signane & .229 & .085 & .209 & 2.689 & .008 \\
\hline & Display & .235 & .095 & .210 & 2.480 & .015 \\
\hline
\end{tabular}

a. Dependent Variable: Keputusan Pembelian

Sumber: Output SPSS 24.0

Melalui perhitungan yang dilakukan dengan menggunakan program SPSS, maka perbandingan antara dengan $\quad(n-k-1)=120-2-1=117(1.9840)$ setiap variabel sebagai berikut :

1. In Store Media yaitu $>\quad(8.193>1.9840)$ dan $(\mathrm{sig} \quad=0,000<0,050)$, hal tersebut menyatakan bahwa adanya pengaruh In Store Media terhadap Keputusan Pembelianpada Pada Produk Pakaian di PT. Matahari Department Store Kota Bengkulu.

2. Signane yaitu $>\quad(2.689>1.9840)$ dan $(\mathrm{sig}=0,008<0,050)$, hal tersebut menyatakan bahwa adanya pengaruh Signane terhadap Keputusan Pembelianpada Pada Produk Pakaian di PT. Matahari Department Store Kota Bengkulu.

3. Display yaitu $>\quad(2.480>1.9840)$ dan $(\mathrm{sig}=0,015<0,050)$, hal tersebut menyatakan bahwa adanya pengaruh Display terhadap Keputusan Pembelianpada Pada Produk Pakaian di PT. Matahari Department Store Kota Bengkulu.

\section{Pengujian Hipotesis Dengan Uji F}

200 | Sukardi Putra; Furqonti Ranidiah; Ade Tiara Yulinda; Pengaruh Point Of Purchase (Pop)... 
Untuk menguji pengaruh variabel bebas secara parsial terhadap variabel terikat digunakan uji $\mathrm{F}$ sebagai berikut :

Tabel 4. Hasil Pengujian Hipotesis dengan Uji F

\begin{tabular}{|l|r|r|r|r|r|r|}
\hline \multicolumn{7}{|c|}{ ANOVA $^{\text {a }}$} \\
\hline \multirow{2}{*}{ Model } & $\begin{array}{c}\text { Sum of } \\
\text { Squares }\end{array}$ & Df & $\begin{array}{c}\text { Mean } \\
\text { Square }\end{array}$ & F & ig. \\
\hline \multirow{2}{*}{1} & Regression & 441.160 & 3 & 147.053 & 84.966 & $.000^{\mathrm{b}}$ \\
\cline { 2 - 7 } & Residual & 200.765 & 116 & 1.731 & \\
\cline { 2 - 8 } & Total & 641.925 & 119 & & & \\
\hline
\end{tabular}

a. Dependent Variable: Keputusan Pembelian

b. Predictors: (Constant), Display, Signane,In Store Media

Sumber: Output SPSS 24.0

Berdasarkan tabel uji hipotesis dengan uji $\mathrm{F}$ diatas diperoleh $\quad$ F sebesar 84.966 dengan nilai $\quad$ sebesar 3.9200 yaitu $(84.966>3.9200)$ dan $(\mathrm{sig}=0.000<0,050)$, maka dengan demikian dapat disimpulkan bahwa diterima artinya secara simultan variabel In Store Media ( ), Signane $\left(\mathrm{X}_{2}\right)$ Display $\left(\mathrm{X}_{3}\right)$ dan berpengaruh secara signifikan terhadap Keputusan Pembelian (Y) di Pada Produk Pakaian di PT. Matahari Department Store Kota Bengkulu.

Berdasarkan hasil penelitian dan pengolahan data mentah yang dilakukan pada Pada Produk Pakaian di PT. Matahari Department Store Kota Bengkulu melalui penyebaran kuesoner terhadap 120 orang responden yang telah diuji sehingga dapat diketahui pengaruh In Store Media ( ), Signane $\left(\mathrm{X}_{2}\right)$ Display $\left(\mathrm{X}_{3}\right)$ berpengaruh secara signifikan Terhadap Keputusan Pembelianpada Pada Produk Pakaian di PT. Matahari Department Store Kota Bengkulu .

Berdasarkan karakteristik responden berdasarkan jenis kelamin laki-laki sebanyak 64 orang responden kemudian jumlah responden perempuan sebanyak 56 orang responden, dapat diketahui bahwa dari responden yang melakukan pembelian produk pakaian di PT. Matahari Department Store Kota Bengkulu, lebih didominasi oleh responden yang berjenis kelamin lakilaki.Hal ini biasa terjadi, karena para laki-laki cenderung untuk langsung menuju ke area produk yang ingin dibelinya tanpa berjalan mengelilingi area belanja untuk melihat-lihat produk lain terlebih dahulu dan beragam pilihan sedangkan perempuan cenderung melihat-lihat atau mengelilingi area terlebih dahulu sebelum melakukan pembelian misalnya perempuan berencana untuk membeli baju kaos, tapi pada saat berjalan menuju ke area baju kaos, dia melihat pajangan sepatu dan timbul adanya keinginan untuk membeli produk sepatu tersebut maka hal ini banyak laki-laki yang menggunakan produk pakaian di PT. Matahari Department Store Kota Bengkulu. Berdasarkan umur yang paling mendominasi umur 26 - 30 responden, dari data tersebut menyatakan bahwa secara keseluruhan responden yang melakukan pembelian di PT. Matahari Department Store kota Bengkulu, didominasi oleh mereka yang umur 26-30 tahun. Hal ini terjadi, karena pada usia 26-30 tahun, seseorang cenderung untuk memperhatikan penampilan dan pengaruh potongan harga yang diberikan PT. Matahari Department Store, kota Bengkulu, juga alasan kuat yang mendorong mereka untuk melakukan pembelian karena harga produk yang ditawarkan kepada konsumen cukup terjangkau. Berdasarkan pendidikan terakhir yang paling mendominasi SMA sebanyak 33 responden dengan persentase 39,3\%. Dari data tersebut dapat disimpulkan bahwa Pada Produk Pakaiandi PT. Matahari Department Store Kota Bengkulu sudah memiliki pendidikan yang cukup tinggi. 
Berdasarkan deskripsi pada tanggapan responden, hasil analisis penilaian responden terhadap variabel In Store Media ( ) indikator nada-nada popular memiliki nilai rata-rata tertinggi yaitu 4.01 karena menurut responden PT.Matahari Department Store sudah menggunakan nada-nada popular untukmenarik perhatian konsumen. Pada variabel signane penilaian dilakukan dengan empat indikator.

Adapun hasil analisis penilaian responden pada tabel 4.7 Terhadap variabel Signane ( ) indikator Signanepernyataan nomor 2 memiliki nilai rata-rata tertinggi yaitu 3.76 yaitu PT. Matahari Department Store sudah menggunakan Label Signane In store media, seperti label harga, size dan label brand pada setiap produk sehingga membuat konsumen dapat mempertimbangkan dengan mudah untuk membeli.

Pada variabel Display penilaian responden memiliki nilai rata-rata tertinggi yaitu 3.76 dan memiliki rata-rata terendah yaitu 3,84 pada nomor 2 yaitu PT.Matahari Department Store sudah menggunakan interior Display untuk barang -barang yang sudah dikenal luas oleh masyarakat, misalnya produk Polo, alt $N$ Paper, Lois dan Rip Curldipajang di Display. Selanjutnya variabel Keputusan Pembelian indikator konsumen akan membeli Produk pakaian di PT. Matahari Department Store karena terbiasa membeli Produk pakaian di PT. Matahari Department Store memiliki rata-rata tertinggi yaitu 4.03, artinya responden yang memutuskan berbelanja pakaian memang sudah terbiasa berbelanja di PT. Matahari Department Store.

\section{Kesimpulan}

\section{KESIMPULAN DAN SARAN}

Berdasarkan hasil penelitian yang telah dilakukan tentang pengaruh In Store Media ( ）, Signane $\left(\mathrm{X}_{2}\right)$, danDisplay $\left(\mathrm{X}_{3}\right)$ Terhadap Keputusan Pembelian $(\mathrm{Y})$ Pada Produk Pakaian di PT. Matahari Department Store Kota Bengkulu, dapat disimpulkan sebagai berikut :

1. In Store Media berpengaruh terhadap Keputusan Pembelianpada Pada Produk Pakaian di PT. Matahari Department Store Kota Bengkulu, hal ini dibuktikan dengan hasil uji t menunjukan nilai $>(8.193>1.9840)$ dan $(\mathrm{sig}=0,000<0,050)$. Ini berarti ditolak dan diterima.

2. Signaneberpengaruh signifikan terhadap Keputusan Pembelianpada Pada Produk Pakaian di PT. Matahari Department Store Kota Bengkulu, hal ini dibuktikan dengan hasil uji t menunjukan nilai $>(2.689>1.9840)$ dan $(\mathrm{sig}=0,043<0,050)$. Ini berarti ditolak dan diterima.

3. Displayberpengaruh signifikan terhadap Keputusan Pembelianpada Pada Produk Pakaian di PT. Matahari Department Store Kota Bengkulu, hal ini dibuktikan dengan hasil uji t menunjukan nilai $>(2.480>1.9840)$ dan $(\mathrm{sig}=0,034<0,050)$. Ini berarti ditolak dan diterima.

4. In Store Media ( ), Signane $\left(\mathrm{X}_{2}\right)$, dan Display $\left(\mathrm{X}_{3}\right)$ secara bersama-sama berpengaruh terhadap Keputusan Pembelian (Y) pada Pada Produk Pakaian di PT. Matahari Department Store Kota Bengkulu, hal ini dibuktikan dengan uji F menunjukkan nilai $\quad F>$,yaitu yaitu $(84.966>3.9200)$ dan $(\operatorname{sig}=0.000<0,050)$. Ini berarti ditolak dan diterima.

5. Berdasarkan uji koefisien korelasi didapat nilai $\mathrm{R}=0.804$ dan koefisien determinasi $=0,646$ nilai mempunyai makna bahwa In Store Media ( ), Signane $\left(\mathrm{X}_{2}\right)$, dan Display $\left(\mathrm{X}_{3}\right)$ memberikan kontribusi yang signifikan pengaruh sebesar 0, 646 atau 64.6\% terhadap Keputusan Pembelian (Y) pada Pada Produk Pakaian di PT. Matahari Department Store Kota Bengkulu sedangkan sisanya sebesar 0.313 atau 31.3\% dipengaruhi oleh variabelvariabel lain yang tidak termasuk dalam penelitian ini.

202 | Sukardi Putra; Furqonti Ranidiah; Ade Tiara Yulinda; Pengaruh Point Of Purchase (Pop)... 


\section{Saran}

Berdasarkan hasil penelitian, pembahasan dan kesimpulan yang diperoleh, maka saran yang dapat diberikan sebagai berikut :

1. Hasil penelitian menunjukan adanya pengaruh antara variabel In Store Media ( ), Signane $\left(\mathrm{X}_{2}\right)$, dan Display $\left(\mathrm{X}_{3}\right)$ signifikan terhadap Keputusan Pembeliann(Y) Pada Pada Produk Pakaian di PT. Matahari Department Store Kota Bengkulu, variabel Displaymemiliki ratarata terendah yaitu 3.50. Disarankan untuk lebih baiknya perlu ditingkatkan lagi, seperti perbanyak mengikuti trens yang terjadi serta memperhatikan kualitas dan mutu produk yang baik dan lain-lain agar dapat meningkatkan Keputusan Pembelianpada Pada Produk Pakaian di PT. Matahari Department Store Kota Bengkulu .

2. Hasil penelitian terlihat bahwa pada variabel In Store Media memiliki tanggapan responden yang terendah yaitu 3,71 dikarenakan pengusaha kurang memperhatikan apa yang dibutuhkan dalam menawarkan produk. Disarankan sebaiknya para pengusaha dapat lebih aktip dalam mencari dan memahami apa yang diinginkan oleh pasar sasaran agar dapat meningkatkan Keputusan Pembelianyang lebih efektif.

3. Hasil penelitian terlihat bahwa pada variabel Displaymemiliki tanggapan responden yang terendah yaitu 3,66 dikarenakan para konsumen melakukan kegiatan-kegiatan yang dapat merangsang minat konsumen seperti melakukan pertunjukan dan pameran-pameran. Disarankan pengusaha dapat memperkenalkan produknya dengan melakukan acara rutin seperti pertunjukan dan pameran-pameran daerah, agar dapat meningkatkan Keputusan Pembelian.

4. Disarankan bagi peneliti selanjutnya khususnya penelitian yang sama perlu dipertimbangkan untuk In Store Media ( ), Signane $\left(\mathrm{X}_{2}\right)$, dan Display $\left(\mathrm{X}_{3}\right)$ terhadap Keputusan Pembelian (Y) serta diluar variabel Faktor-Faktor terhadap Keputusan Pembeliannserta dapat mengembangkan jumlah respondennya sehingga akan menghasilkan penelitian yang lebih baik dan sesuai dengan peningkatan kualitas penelitian selanjutnya.

\section{DAFTAR PUSTAKA}

Bob Faster. 2008. Manajemen Bisnis Ritel, Andi, Yogyakarta.

Boy Walker, 2007. Marketing Communication Taktik dan Strategi, Bhuana Ilmu Populer, Jakarta.

Engel, J. F., Blackwell, R. D., \& Miniard, P.W. 1995. Perilaku konsumen, Edisi keenam (terjemahan). Binarupa Aksara. Jakarta.

Goni, Roy. 1991, “POP Advertising Alat Bantu Penjualan yang Strategis."Manajemen Usahawan, Jakarta.

Ichwan Adhi. Pamungkas, Pengaruh Point Of Purchase (POP) Terhadap Keputusan Pembelian konsumen Di Toko Luwes Nusukan SurakartaTahun 2013.

Kasali R. (1992), Manajemen Periklanan: Konsep dan Aplikasinya di Indonseia, Pustaka Utama Grafiti, Jakarta.

Kotler P, Keller KL. (2009), Manajemen Pemasaran.Edisi Ketiga Belas, Jilid 1, Bob Sabran, penerjemah, Erlangga, Jakarta.

Lawrence K Frank (2011).Prilaku Konsumen. Jakarta: Binarupa Aksara.

Novrianto dkk (2016).Manajemen Pemasaran dan Pemasaran Jasa. Bandung: Alfabeta.

Nyken Widyastuti dan Retno Tanding Suryandari (2004). Sebuah Dunia (Tanpa Promosi Penjualan.Mix Marketing Xtra, Jakarta.

Pamungkas, W. S. (2013).Linieritas.Universitas Muhammadiyah Yogyakarta.

Rini Suryantini,2001., Manajemen Pemasaran . Jakarta: Penerbit Bumi Aksara. 
Semenik, dkk. (2012),Advertising and Promotions:An Integrated Brand Approach, Sixth Edition, International Edition, Thomson - South Western, USA.

Shimp T. (2003), Periklanan Promosi Dan Aspek Tambahan Komunikasi Pemasaran Terpadu,Edisi Kelima, Jilid 1, Revyani Sahrial \& Dyah Anikasari, Penerjemah, Erlangga, Jakarta.

Sopiah, Syihabudhin, 2008, Manajemen Bisnis Ritel, Andi, Yogyakarta.

Sugiyono. 2010. Metode Penelitian Kuantitatif dan kualitatif, Penerbit Alfabeta, Bandung.

Sugiyono. 2012. Metode Penelitian Kuantitatif Kualitatif dan R\&D. Bandung: Alfabeta.

Sugiyono. 2013. Metode Penelitian Kuantitatif, Kualitatif, dan R\&D. Bandung: CV Alfabeta.

Suharsimi, Arikunto. 2013. Dasar Dasar Evaluasi Pendidilkan. Jakarta. Rineka Cipta.

Sumarwan U. (2011), Perilaku Konsumen Teori dan Penerapannya dalam Pemasaran, Ghalia Indonesia, Bogor.

204 | Sukardi Putra; Furqonti Ranidiah; Ade Tiara Yulinda; Pengaruh Point Of Purchase (Pop)... 